\title{
MENINGKATKAN MINAT BACA MAHASISWA DENGAN STRATEGI PEMBERIAN PERTANYAAN MATA KULIAH TEORI BILANGAN
}

\author{
Uki Suhendar \\ FKIP, Universitas Muhammadiyah Ponorogo \\ ukisuhendar90@gmail.com
}

\begin{abstract}
ABSTRAK
Penelitian ini bertujuan untuk meningkatkan minat baca mahasiswa pada mata kuliah Teori Bilangan menggunakan strategi pemberian pertanyaan di awal pembelajaran. Diharapkan mahasiswa lebih berminat membaca materi untuk mempersiapkan diri dalam menjawab pertanyaan. Penelitian ini merupakan penelitian tindakan kelas (PTK) dalam dua siklus. Objek penelitian ini adalah mahasiswa semester dua Prodi Pendidikan Matematika Universitas Muhammadiyah Ponorogo. Teknik pengumpulan data menggunakan penyebaran angket minat baca. Teknik analisis data dengan analisis deskriptif terhadap lembar hasil pengisian angket minat baca. Berdasarkan hasil penelitian ini disimpulkan bahwa penerapan strategi pemberian pertanyaan yang dapat meningkatkan minat baca mahasiswa pada mata kuliah Teori Bilangan adalah tiap mahasiswa diberikan pertanyaan terkait materi perkuliahan. Setelah seluruh mahasiswa diberikan pertanyaan, lalu kelas dimulai dengan menggunakan suatu pendekatan atau model pembelajaran yang lain. Disamping penerapan strategi tersebut perlu diberikan upaya perbaikan berupa reward yakni penilaian dari jawaban masing-masing mahasiswa sebagai nilai keaktifan, materi yang digunakan untuk tanya jawab adalah materi yang telah dan akan dipelajari, dan mahasiswa dimotivasi untuk membaca lebih giat lagi.
\end{abstract}

Kata Kunci: minat baca, strategi pertanyaan, teori bilangan

\begin{abstract}
This research intends to increase students' interest in reading in Number Theory subjects using the strategy of giving questions at the beginning of learning. It is expected that students are more interested in reading material to prepare themselves in answering questions. This research is a classroom action research (CAR) in two cycles. The object of this research is the second semester students. Data collection techniques use questionnaires of reading interest. Data analysis techniques with descriptive analysis from the results of filling questionnaires of reading interest. Based on the results, it was concluded that the application of the strategy of giving questions that can increase students' interest in reading in Number Theory subjects is each student is given questions related to lecture material. After all students are given questions, then the class begins using an approach or another learning model. Besides the implementation of these strategies, it is necessary to provide remedial efforts in the form of rewards, namely the assessment of the answers of each student as activeness values, the material used for question and answer is material that has been and will be studied, and give motivation to students to read harder.
\end{abstract}

Keywords: reading interest, question strategy, number theory 


\section{PENDAHULUAN}

Membaca adalah tindakan nyata seseorang dalam memahami materi. Mahasiswa harus mempunyai minat atau keinginan dalam membaca. Mahasiswa sebagai sumber daya manusia Indonesia sangat dibutuhkan ide dan pendapatnya untuk membangun negeri ini. Kualitas Sumber Daya Manusia (SDM) ini sangat terkait dengan minat membaca yang dimiliki mahasiswa (Siswati, 2010). Pendapat tersebut mengungkapkan betapa pentingnya minat baca bagi seorang mahasiswa. Dengan memiliki mahasiswa-mahasiswa yang minat bacanya tinggi, akan meningkatkan kualitas SDM.

Menurut Rahma dkk (2015), minat baca adalah dorongan yang dapat mempengaruhi perilaku dan tindakan yang kemudian diikuti dengan perasaan senang dan ketertarikan terhadap kegiatan membaca. Dahlan (2008) menyatakan bahwa minat dapat menjadi daya pendorong atau motivasi bagi seseorang untuk melakukan sesuatu. Dengan demikian minat baca berarti dorongan atau motivasi untuk membaca.

Namun, berdasar hasil wawancara dengan mahasiswa, dapat disimpulkan bahwa mahasiswa prodi Pendidikan Matematika semester 2 masih kurang maksimal dalam membaca materi. Setiap kali diberi tugas membaca materi perkuliahan, hanya beberapa mahasiswa saja yang melakukan. Seringkali mahasiswa tidak siap materi dalam mengikuti perkuliahan. Sehingga ketika dijelaskan materi perkuliahan, banyak mahasiswa yang masih belum fokus karena belum siap materi yang dipelajari. Akibat kurang fokusnya mahasiswa dalam perkuliahan menyebabkan kurang maksimalnya pemenuhan indikator capaian yang diharapkan.

Menurut hasil penelitian Anugra dkk (2013), keadaan lingkungan sosial yang lebih kondusif merupakan faktor yang paling dominan mempengaruhi minat baca mahasiswa, disusul rasa ingin tahu yang tinggi atas fakta, teori, prinsip, pengetahuan dan informasi. Ketika dosen mengupayakan kegiatan pembelajaran yang mengedepankan kegiatan membaca, maka akan membuat mahasiswa terbiasa membaca. Selain itu, mahasiswa dibiasakan memiliki rasa ingin tahu yang tinggi dengan diberikan pertanyaan.

Dahlan (2008) menyatakan cara yang dapat dilakukan oleh guru adalah dengan memberi tugas kepada murid untuk membaca satu buku dan membuat ringkasannya atau anotasinya. Dalam penelitian ini, mahasiswa dituntut membaca kemudian dievaluasi dengan diberi pertanyaan terkait materi yang telah dibaca. Hal ini juga sesuai dengan pendapat dari Dahlan (2008), yakni untuk meningkatkan minat salah satunya adalah mahasiswa dimotivasi oleh keadaan yang menyebabkan mereka harus melakukannya untuk mencapai suatu tujuan. Tujuan dalam hal ini adalah dapat menjawab pertanyaan-pertanyaan yang diberikan oleh guru.

Berdasarkan hasil penelitian yang diperoleh Hardi, dkk (2014), disarankan bahwa dosen hendaknya melakukan proses pembelajaran yang lebih mengaktifkan mahasiswa untuk banyak membaca buku. Dengan demikian mahasiswa akan dapat meningkatkan kualitas dirinya. Peran dosen dibutuhkan untuk mengembangkan atau lebih tepatnya membudayakan kebiasaan membaca pada mahasiswa. Seperti yang disebutkan oleh Kasiyun (2015) bahwa upaya meningkatkan minat baca merupakan tanggung jawab bersama, salah satunya oleh pendidik. Perkuliahan yang menggunakan strategi mengaktifkan mahasiswa membaca buku adalah salah satu upaya meningkatkan minat baca. Karena minat baca yang dimiliki akan 
mengoptimalkan berkembangnya pengetahuan ataupun wawasan dari yang dimiliki mahasiswa.

Menurut Sumarwati dan Purwadi (2010), pembuatan pertanyaan awal yang dilakukan di bawah bimbingan guru dan atau bersama-sama teman yang setara kemampuannya memungkinkan dihasilkannya pertanyaan awal yang relevan dengan isi teks dan mencapai tingkat pemahaman. Jadi dengan pemberian pertanyaan awal pembelajaran diharapkan dapat digunakan untuk meningkatkan pemahaman mahasiswa. Pemahaman mahasiswa dapat diperoleh salah satunya dari hasil mereka membaca materi perkuliahan. Hasil penelitian Suprapto, dkk (2013) juga menguatkan bahwa penerapan proses pembelajaran dengan bertanya dapat meningkatkan keterampilan berpikir yang dimiliki siswa. Dengan keterampilan berpikir yang baik tentu akan mendukung ketercapaian indikator perkuliahan sesuai yang diharapkan.

Frase, Patrick, dan Schumer (dalam Sumarwati dan Purwadi, 2010) menyatakan bahwa untuk mengaktivasi pengetahuan awal, salah satu strategi yang dapat diterapkan adalah pembuatan pertanyaan awal. Artinya, strategi pemberian pertanyaan kepada mahasiswa dapat membuat mereka lebih fokus dengan pembelajaran. Sehingga mahasiwa akan berusaha menyiapkan diri dengan membaca materi terlebih dahulu agar dapat menjawab pertanyaan awal. Tujuan dari penelitian ini adalah mendeskripsikan penerapan dari strategi pemberian pertanyaan yang dapat meningkatkan minat baca mahasiswa pada mata kuliah Teori Bilangan.

Menurut Suhendar dan Widjajanti (2016) salah satu upaya meningkatkan minat adalah memberi kesempatan siswa untuk mengevaluasi hasil kerjanya. Hal ini tentu dapat dilakukan dengan memberikan pertanyaan terkait materi yang harus sudah dibaca oleh mahasiswa. Dengan demikian diharapkan minat baca mahasiswa akan dapat meningkat.

Langkah-langkah strategi pemberian pertanyaan yang digunakan dalam penelitian ini adalah tiap mahasiswa diberikan pertanyaan terkait materi perkuliahan. Selanjutnya seluruh mahasiswa diberikan pertanyaan, lalu kelas dimulai dengan menggunakan suatu pendekatan atau model pembelajaran yang lain. Dengan langkah ini diharapkan mahasiswa dapat meningkat minat bacanya.

Dalam melakukan penelitian, tentunya dibutuhkan data yang akan dijadikan dasar menarik kesimpulan. Berdasarkan pendapat dari Krismanto, Handayani, dan Sudarsana (dalam Rahma dkk, 2015), minat baca dapat diukur melalui beberapa aspek, yakni aspek kesadaran akan manfaat membaca, perhatian terhadap membaca buku, rasa senang terhadap membaca buku, dan frekuensi membaca buku. Keempat aspek tersebut akan digunakan peneliti sebagai acuan untuk menyusun instrumen penelitian berupa angket minat baca.

Penelitian ini bertujuan untuk meningkatkan minat baca mahasiswa pada mata kuliah Teori Bilangan menggunakan strategi pemberian pertanyaan di awal pembelajaran.

\section{METODE}

Jenis penelitian ini adalah Penelitian Tindakan Kelas (PTK). Rancangan yang digunakan adalah model Kemmis \& Mc. Taggart. Langkah-langkahnya meliputi perencanaan (plan), melakukan tindakan (action) dan pengamatan (observe) sekaligus, dan mengadakan refleksi (reflection). Ketiga langkah ini dinamakan siklus 
dan berbentuk spiral. Siklus akan terus berlanjut dan berhenti saat indikator keberhasilan tercapai.

Penelitian ini dilaksanakan di kelas mata kuliah Teori Bilangan pada Prodi Pendidikan Matematika Universitas Muhammadiyah Ponorogo. Lokasi penelitian di Jl. Budi Utomo No 10 Ponorogo. Dilaksanakannya saat perkuliahan semester genap tahun 2017-2018. Objek penelitian adalah mahasiswa program studi Pendidikan Matematika semester dua tahun akademik 2017-2018. Objek ini diteliti tentang minat baca mahasiswa pada mata kuliah Teori Bilangan setelah dilakukan pembelajaran dengan strategi pemberian pertanyaan. Penelitian dilaksanakan pada pembelajaran mata kuliah Teori Bilangan.

Pada tahap perencanaan disusun perangkat perkuliahan dan instrumen penelitian yang digunakan, meliputi penyusunan RPS dan bahan ajar yang sesuai dengan materi yang ditentukan. Kemudian membuat angket minat baca mahasiswa dengan sebelumnya menentukan kisi-kisi yang sesuai dengan aspek minat baca. Angket inilah yang nantinya digunakan sebagai alat pengumpul data minat baca yang dimiliki mahasiswa.

Tahap melakukan tindakan dan pengamatan adalah melaksanakan apa yang telah direncanakan sebelumnya. Melakukan perkuliahan menggunakan strategi pemberian pertanyaan. Selama proses perkuliahan, proses yang terjadi di kelas dan keterlaksanaan langkah-langkah strategi pemberian pertanyaan yang dilakukan mahasiswa diamati. Di akhir siklus diberikan angket untuk mengetahui tingkat minat baca mahasiswa setelah tindakan dengan strategi pemberian pertanyaan. Data angket minat baca mahasiswa selanjutnya dikelompokkan sesuai dengan masing-masing aspek minat baca. Setelah pengelompokan ini dilakukan analisis dan ditentukan apakah sudah mencapai indikator keberhasilan atau belum.

Tahap terakhir, yakni tahap refleksi. Dilakukan refleksi atas apa yang telah dilaksanakan dan juga terhadap hasil pengamatan. Bila indikator keberhasilan belum tercapai, maka pada tahap ini juga dikaji apa kelemahan dari pelaksanaan siklus sebelumnya. Hasil refleksi ini kemudian dijadikan perbaikan untuk pelaksanaan siklus selanjutnya. Apabila telah mencapai indikator keberhasilan, maka siklus penelitian dihentikan.

Instrumen yang digunakan dalam penelitian ini adalah angket minat baca mahasiswa. Angket ini terdiri dari 20 butir pernyataan dengan skala Likert 1-4. Sebelum membuat angket, terlebih dahulu dibuat kisi-kisinya. Data hasil penelitian ini diolah dengan mencari skor rata-rata tiap aspek minat baca. Kemudian dikelompokkan dalam tiga kategori, yaitu mempunyai tinggi, sedang, atau rendah. Kategori ini didasarkan pada tabel 1 berikut.

Tabel 1. Kriteria kategori minat baca

\begin{tabular}{cc}
\hline Jumlah skor & Kategori \\
\hline $56-75$ & Tinggi \\
$36-55$ & Sedang \\
$15-35$ & Rendah \\
\hline
\end{tabular}

Indikator keberhasilan dalam penelitian ini adalah apabila tidak ada aspek minat baca yang berada pada kategori rendah. 


\section{HASIL DAN PEMBAHASAN}

Hasil penelitian ini dijelaskan sesuai dengan tahapan dari Penelitian Tindakan Kelas dalam tiap siklus, yakni perencanaan, pelaksanaan dan observasi, serta refleksi. Pada tahap perencanaan, peneliti menyusun RPS terlebih dahulu dengan menyelipkan proses strategi pemberian pertanyaan di awal pembelajaran. Selanjutnya menyiapkan bahan ajar yang sesuai dengan tujuan pembelajaran. Kemudian peneliti menyusun kisi-kisi instrumen penelitian, yakni angket minat baca. Angket ini terdiri dari 15 butir pernyataan dari empat aspek minat baca. Angket ini diberikan pada setiap akhir siklus.

Tahap berikutnya adalah pelaksanaan penelitian berdasarkan apa yang sudah direncanakan. Untuk siklus 1 dilaksanakan dalam 2 pertemuan, pada awal pembelajaran dilakukan tanya jawab kepada masing-masing mahasiswa. Pertanyaan yang diberikan meliputi materi yang telah dipelajari. Pertemuan sebelumnya mahasiswa juga sudah diingatkan untuk membaca materi yang akan dipelajari. Akan tetapi saat pertemuan pertama di siklus 1, sebagian besar mahasiswa masih belum bisa menjawab pertanyaan dari dosen. Masih banyak mahasiswa mencari jawaban pertanyaan di bahan ajar saat pelaksanaan proses tanya jawab. Menandakan bahwa mereka belum membaca materi sebelum perkuliahan.

Saat pertemuan kedua, beberapa mahasiswa sudah dapat menjawab pertanyaan dengan benar tanpa membaca saat proses tanya jawab. Akan tetapi dari 4 mahasiswa yang diwawancarai, 3 mahasiswa mengaku masih terpaksa untuk membaca sebelum pembelajaran agar dapat menjawab pertanyaan. Keempat mahasiswa juga baru membaca pada 1 hari sebelum pelaksanaan pembelajaran, dengan frekuensi membaca kurang dari 3 jam. Hal ini menunjukkan mahasiswa masih terpaksa membaca karena ada pertanyaan yang harus dijawab. Akan tetapi karena tidak ada penilaian dari jawaban mereka, yang mana jawaban ini tidak berimbas ke nilai mereka, maka masih banyak yang membaca hanya sebentar saja. Masalah selanjutnya, ketika mahasiswa diberi pertanyaan terkait materi yang akan dipelajari, mereka tidak dapat menjawab dengan alasan belum sempat membaca. Belum membiasakan diri untuk membaca masih terlihat di pertemuan kedua ini. Hingga peneliti yakin ada yang perlu diperbaiki dari proses perkuliahan.

Setelah dua pertemuan dilaksanakan dengan strategi pemberian pertanyaan di awal pembelajaran, kemudian dilakukan pengumpulan data dengan mengisi angket minat baca. Kemudian hasil pengisian angket ini diolah berdasarkan tiap indikator minat baca. Hasil dari pengolahan data pada akhir siklus 1 adalah masih ada dua aspek yang masih tergolong rendah. Yakni pada aspek rasa senang terhadap membaca buku dan frekuensi membaca buku. Hasil ini sesuai dengan hasil wawancara dengan mahasiswa saat pelaksanaan pembelajaran. Masih banyak mahasiswa yang terpaksa membaca bahan ajar saat proses tanya jawab. Selain itu mahasiswa hanya membaca materi yang sudah disampaikan sebelumnya, tapi belum mempelajari materi yang akan dipelajari. Berbagai alasan yang dikemukakan oleh mahasiswa terkait alasan rendahnya aktivitas membaca mereka pada kedua aspek yang masih kurang ini.

Tahap selanjutnya adalah tahap refleksi. Hasil yang telah diperoleh masih belum mencapai indikator keberhasilan. Beberapa kelemahan saat pelaksanaan siklus 1 adalah mahasiswa masih terpaksa membaca karena tidak ada imbas ke nilai mereka. Selain itu mahasiswa masih membaca materi yang telah dipelajari saja, tetapi tidak membaca materi yang akan dipelajari. Frekuensi membaca mahasiswa 
juga masih kurang optimal. Upaya perbaikan yang dilakukan untuk siklus 2 antara lain adalah reward yakni penilaian dari jawaban masing-masing mahasiswa sebagai nilai keaktifan. selain itu, materi yang digunakan untuk tanya jawab adalah materi yang telah dan akan dipelajari. Terakhir, mahasiswa dimotivasi untuk membaca lebih giat lagi.

Penelitian dilanjutkan ke siklus 2, dengan menerapkan upaya perbaikan yang telah direncanakan. Sebelum pertemuan pertama di siklus 2, mahasiswa diberi tahu untuk membaca materi yang telah maupun yang akan dipelajari karena akan jadi penilaian keaktifan. Saat pelaksanaan pembelajaran di siklus 2, baik pertemuan pertama maupun kedua, mahasiswa sudah terlihat lebih siap dibanding siklus sebelumnya. Hampir seluruh mahasiswa dapat menjawab pertanyaan, walaupun beberapa jawabannya masih belum sempurna. Setiap akhir pertemuan, mahasiswa dimotivasi untuk membaca materi baik yang telah dipelajari maupun yang akan dipelajari. Hal ini mengikuti hasil penelitian dari Hayati (2009) yakni guru seharusnya memotivasi peserta didik agar senang membaca. Dengan adanya motivasi dari guru mengakibatkan mahasiswa menyadari pentingnya membaca materi sebelum proses perkuliahan.

Saat pertemuan kedua siklus 2, dicoba untuk tidak melakukan tanya jawab, mahasiswa langsung memberi respon kenapa tidak ada tanya jawab padahal mereka sudah siap. Hal ini dilakukan hanya untuk mengetahui respon mahasiswa seandainya tidak dilakukan tanya jawab. Respon yang mahasiswa berikan menunjukkan bahwa mereka sudah membaca materi. Setelah mengetahui respon mahasiswa, peneliti tetap melakukan proses tanya jawab sebelum pembelajaran. Saat peneliti melakukan wawancara kepada mahasiswa yang sama seperti di siklus 1, mereka menjawab mulai berminat membaca karena adanya proses penilaian dari hasil tanya jawab sebelum pembelajaran. Mereka jadi termotivasi untuk membaca tidak hanya mendekati pembelajaran, tetapi setiap ada waktu mereka membaca materi perkuliahan. Bahkan beberapa mengungkapkan bahwa ada manfaat yang mereka peroleh setelah mereka mempersiapkan diri mempelajari materi sebelum perkuliahan, salah satunya lebih mudah mengikuti proses perkuliahan.

Setelah pelaksanaan siklus 2 , hasil yang diperoleh telah mencapai indikator keberhasilan, yakni tidak ada aspek yang berada pada kategori rendah. Meskipun untuk dua aspek yang sebelumnya pada kategori sedang tidak mengalami peningkatan kategori, namun secara rata-rata nilai kedua aspek mengalami peningkatan. Secara ringkas, hasil analisis data penelitian ini dapat direkap pada tabel 2 berikut.

Tabel 2. Kriteria hasil minat baca peraspek

\begin{tabular}{ccc}
\hline Aspek ke- & Akhir siklus 1 & Akhir siklus 2 \\
\hline 1 & Sedang & Sedang \\
2 & Sedang & Sedang \\
3 & Rendah & Sedang \\
4 & Rendah & Sedang \\
\hline
\end{tabular}


Aspek minat baca dalam penelitian ini terdiri dari 4 aspek, yakni aspek kesadaran akan manfaat membaca, perhatian terhadap membaca buku, rasa senang terhadap membaca buku, dan frekuensi membaca buku. Keempat aspek ini menjadi pengukur minat baca yang dimiliki mahasiswa. Apabila keseluruhan aspek telah berkategori minimal sedang, maka penelitian dihentikan.

Setelah dilaksanakan dalam 2 siklus, diperoleh hasil bahwa indikator keberhasilan penelitian ini tercapai. Keseluruhan aspek minat baca mahasiswa tidak berada pada kategori rendah lagi. Walaupun keseluruhan aspek masih berada pada kategori sedang, namun telah ada peningkatan pada skor rata-rata setiap aspeknya. Pada awalnya mahasiswa terpaksa membaca karena penerapan strategi pemberian pertanyaan, namun mereka akhirnya terbiasa membaca. Bahkan ketika ada waktu luang mereka menyempatkan untuk membaca materi perkuliahan, tidak lagi membaca sehari sebelum pembelajaran. Hal ini sesuai dengan pendapat Rahma, dkk (2015), bahwa minat baca adalah dorongan yang dapat mempengaruhi perilaku dan tindakan yang kemudian diikuti dengan perasaan senang dan ketertarikan terhadap kegiatan membaca.

Salah satu upaya perbaikan dari siklus 1 adalah pemberian reward berupa nilai keaktifan bagi mahasiswa yang dapat menjawab pertanyaan. Hal ini karena mahasiswa pada siklus 1 belum termotivasi membaca karena tidak ada akibat apabila tidak dapat menjawab pertanyaan. Sejalan dengan pendapat Suhendar dan Widjajanti (2016) bahwa salah satu upaya meningkatkan minat adalah memberi kesempatan siswa untuk mengevaluasi hasil kerjanya. Hal ini diperkuat pendapat Dahlan (2008), yakni untuk meningkatkan minat salah satunya adalah mahasiswa dimotivasi oleh keadaan yang menyebabkan mereka harus melakukannya untuk mencapai suatu tujuan. Tujuan dalam hal ini adalah dapat menjawab pertanyaan-pertanyaan yang diberikan oleh dosen. Terbukti pada siklus 2 minat mahasiswa sudah meningkat setelah diberikan nilai keaktifan. Bahkan mahasiswa merasa kecewa apabila setelah mereka membaca tidak ada evaluasi apapun. Hal ini membuktikan bahwa ketika ada evaluasi, maka minat membaca mahasiswa pun jadi meningkat.

Menurut hasil penelitian Anugra, dkk (2013), keadaan lingkungan sosial yang lebih kondusif merupakan faktor yang paling dominan mempengaruhi minat baca mahasiswa, disusul rasa ingin tahu yang tinggi atas fakta, teori, prinsip, pengetahuan dan informasi. Ketika dosen mengupayakan kegiatan pembelajaran yang mengedepankan kegiatan membaca, maka akan membuat mahasiswa terbiasa membaca. Selain itu, mahasiswa juga dibiasakan memiliki rasa ingin tahu yang tinggi dengan diberikan pertanyaan. Berdasarkan hasil penelitian yang diperoleh Hardi, dkk (2014), disarankan bahwa dosen hendaknya melakukan proses pembelajaran yang lebih mengaktifkan mahasiswa untuk banyak membaca buku. Dalam penelitian ini, mahasiswa dibiasakan membaca materi perkuliahan sebelum pembelajaran.

Frase, Patrick, dan Schumer (dalam Sumarwati dan Purwadi, 2010) menyatakan untuk mengaktivasi pengetahuan awal, salah satu strategi yang dapat diterapkan adalah pembuatan pertanyaan awal. Artinya, strategi pemberian pertanyaan kepada mahasiswa dapat membuat mereka lebih fokus dengan pembelajaran. Sehingga mahasiwa akan berusaha menyiapkan diri dengan membaca materi terlebih dahulu agar dapat menjawab pertanyaan awal. Terbukti saat pembelajaran di siklus 2, banyak mahasiswa kecewa kalau tidak ada proses tanya jawab karena mereka telah siap. Mereka siap menjawab karena telah membaca materi baik yang telah maupun yang akan dipelajari. Berdasarkan hasil penelitian ini dapat disimpulkan bahwa penerapan strategi pemberian pertanyaan dapat meningkatkan minat baca mahasiswa pada mata kuliah Teori Bilangan. 


\section{SIMPULAN DAN SARAN}

Berdasarkan hasil penelitian ini dapat disimpulkan bahwa penerapan strategi pemberian pertanyaan yang dapat meningkatkan minat baca mahasiswa pada mata kuliah Teori Bilangan adalah tiap mahasiswa diberikan pertanyaan terkait materi perkuliahan. Setelah seluruh mahasiswa diberikan pertanyaan, lalu kelas dimulai dengan menggunakan suatu pendekatan atau model pembelajaran yang lain. Disamping penerapan strategi tersebut perlu diberikan upaya perbaikan berupa reward yakni penilaian dari jawaban masing-masing mahasiswa sebagai nilai keaktifan, materi yang digunakan untuk tanya jawab adalah materi yang telah dan akan dipelajari, dan mahasiswa dimotivasi untuk membaca lebih giat lagi.

Saran untuk penelitian lanjutan adalah penerapan strategi pemberian pertanyaan ini dapat dikombinasikan dengan strategi ataupun model pembelajaran yang lain dalam upaya peningkatan minat baca mahasiswa.

\section{UCAPAN TERIMA KASIH}

Penulis menyampaikan terima kasih kepada Universitas Muhammadiyah Ponorogo, khususnya LPPM UMPo, atas didanainya program penelitian yang menghasilkan luaran berupa artikel ini.

\section{DAFTAR PUSTAKA}

Anugra, H., Yusup, P.M., dan Erwina, W. 2013. Faktor-faktor Dominan yang Mempengaruhi Minat Baca Mahasiswa. Jurnal Kajian Informasi \& Perpustakaan, Vol. 1(2) : 137-145.

Dahlan, M. 2008. Motivasi Minat Baca. Jurnal Iqra', Vol. 2(1) : 21-32.

Hardi, Nuraini Asriati, dan Endang Purwaningsih. 2014. Pengaruh Minat Membaca Buku Terhadap Hasil Belajar Mahasiswa BKK Akuntansi. Skripsi tidak dipublikasikan. Pontianak : Program Studi Pendidikan Ekonomi Universitas Tanjungpura.

Hayati, Nur. 2009. Faktor-faktor yang Mempengaruhi Minat Baca Buku Referensi Mata Pelajaran Sosiologi (Kasus Siswa SMA Negeri 1 Sukorejo Kendal Tahun Ajaran 2008/2009). Skripsi tidak dipublikasikan. Semarang : Jurusan Sosiologi dan Antropologi Universitas Negeri Semarang.

Kasiyun, Suharmono. 2015. Upaya Meningkatkan Minat Baca Sebagai Sarana untuk Mencerdaskan Bangsa. Jurnal Pena Indonesia (JPI) Jurnal Bahasa Indonesia, Sastra, dan Pengajarannya, Vol. 1(1) : 79-95.

Rahma, N.M., Pratiwi, R.N., dan Niken, L.V.A. 2015. Strategi Peningkatan Minat Baca Anak (Studi pada Ruang Baca Anak Perpustakaan Umum dan Arsip Daerah Kota Malang). Jurnal Administrasi Publik (JAP), Vol. 3(5) : 763-769.

Siswati. 2010. Minat Membaca pada Mahasiswa (Studi Deskriptif pada Mahasiswa Fakultas Psikologi UNDIP Semester I). Jurnal Psikologi Undip, Vol. 8(2) : 124-134.

Suhendar, U., dan Widjajanti, D.B. 2016. Komparasi Keefektifan Saintifik dan PMRI Ditinjau dari Prestasi, Minat, dan Percaya Diri Siswa Kelas VII. Jurnal Pythagoras, Vol. 11(1) : 91-101.

Sumarwati dan Purwadi. 2010. Pembuatan Pertanyaan Awal pada Kegiatan Prabaca untuk Meningkatkan Kemampuan Membaca Intensif. Jurnal Diksi, Vol. 17(1) : $1-13$. 
Suprapto, N., Suliyanah, dan Admoko, S. 2013. Pembelajaran Fisika di SMA Melalui Pertanyaan (Learning by Questioning) dan Keterampilan Berpikir. Jurnal Penelitian Fisika dan Aplikasinya (JPFA), Vol. 3(2) : 1-11. 